Brit. J. industr. Med., 1965, 22, 321.

\title{
IODINE-AZIDE TEST ON URINE OF PERSONS EXPOSED TO CARBON DISULPHIDE*
}

\author{
BY \\ D. DJURIĆ, N. SURDUČKI, and I. BERKEŠ \\ From the Institute of Occupational Health and the Department of Biochemistry, \\ Pharmaceutical Faculty, Belgrade, Yugoslavia
}

(RECEIVED FOR PUBLICATION FEBRUARY 26, 1965)

\begin{abstract}
The iodine-azide test was performed on the urine of workers exposed to carbon disulphide in a viscose factory. The exposure coefficient was determined before, during, and after the working time, and showed a good correlation with the exposure.

Workers exposed to a high concentration of carbon disulphide could be divided in two groups. The first group showed normal values of the exposure coefficient before work but low values at the end. (The coefficient is inversely related to the exposure.) In the second group, the workers started work with slightly decreased values and ended with greatly decreased ones.

We are pursuing this study to establish why recovery in the second group was not complete.
\end{abstract}

Poisoning by carbon disulphide was first described in the middle of the last century and has remained an important problem ever since. Many papers have been published on the subject, dealing mostly with clinical aspects and often contradictory and confusing in the data they present. In the last 20 years, however, the human metabolism of carbon disulphide has also received attention. This work has been reviewed recently by Brieger (1961) and Djurić (1963) and shows that the estimation of carbon disulphide is not a reliable test of exposure. Of the carbon disulphide inhaled, about $80 \%$ is initially retained, but most is expired later, so that the final retention is about $30 \%$. This is nearly all metabolized. Of that absorbed, only about $1 \%$ is excreted in the urine and appears as 'free' and 'bound' forms in ratios which vary from subject to subject. The determination of carbon disulphide in blood is even less reliable and technically more difficult.

An alternative approach has therefore been developed. Yoshida (1955) noticed that the iodineazide reaction

$$
2 \mathrm{NaN}_{3}+\mathrm{I}_{2} \rightarrow 3 \mathrm{~N}_{2}+2 \mathrm{NaI}
$$

is catalysed by a metabolite present in the urine of exposed animals (Vašák, Vaneček, and Kimmelová, 1963), and a quantitative test was developed on the

*This paper is based on work performed under contract BSS-OHYUG-1 with the U.S. Public Health Service at the Institute of Occupational Health, Belgrade. basis of this reaction (Roubal, Vašák, and Kimmelová, 1963; Vašák, 1963; Vašák et al., 1963). They showed that the iodine-azide reaction is accelerated by organic $-\mathrm{SH}$ and $\mathrm{C}=\mathrm{S}$ compounds and by inorganic sulphides, thiosulphates, and thiocyanates, but not by thioethers, disulphides, sulphones or elementary and ionic sulphur.

In the urine of persons exposed to carbon disulphide, an unidentified metabolite, probably a thiazolidone, is excreted and catalyses the reaction. Vašák (1963) used as an index of exposure the time taken for the iodine colour to disappear; the longer the time, the slower the reaction and the less the exposure. The time does not fall linearly with the concentration of metabolite but exponentially. Results obtained in this way must be corrected for variations in the total daily output of urine. It is impracticable to take 24-hr. urine specimens, so the creatinine concentration was estimated instead. An exposure index was then set up:

$$
E=C \cdot \log t \text {, }
$$

where $E$ is the index, $t$ is the time in seconds to the disappearance of the iodine colour, and $C$ is the concentration of creatinine in milligrams/litre. A low concentration of metabolite gives a high value of $t$, and a high $E$, i.e., the greater the exposure to carbon disulphide the lower the exposure coefficient. If the urine is very dilute, $C$ is low, so $E$ is lowered, i.e., a low concentration in a large volume of urine 
is equivalent to a high concentration in a much smaller one.

Roubal et al. (1963) obtained a very good correlation between $E$ and the total exposure to carbon disulphide. We therefore decided to use this test to evaluate the exposure to carbon disulphide of workers in a Yugoslav factory manufacturing viscose rayon.

\section{Methods}

The iodine-azide test (Vašák et al., 1963) was used as follows.

Reagents.-Iodine-azide reagent: 3 g. sodium azide dissolved in $25 \mathrm{ml} . \mathrm{H}_{2} \mathrm{O}$. To this was added $50 \mathrm{ml}$. of a solution containing $24 \cdot 5 \mathrm{~g}$. $\mathrm{I}_{2}+50 \mathrm{~g}$. KI/l., and the whole was made up to $100 \mathrm{ml}$. Buffer: $\mathrm{NaH}_{2} \mathrm{PO}_{4} \cdot \mathrm{H}_{2} \mathrm{O}, 110 \mathrm{~g} / \mathrm{l}$.

To $1 \mathrm{ml}$. of urine $0.2 \mathrm{ml}$. of buffer was added. Then $1 \mathrm{ml}$. of iodine-azide reagent was added, and the chronometer started simultaneously. The test-tube was shaken gently, and the time when the iodine colour disappeared was recorded. Starch filter paper strips were used to increase the accuracy of the end-point. Estimations were carried out in duplicate.

Creatinine was estimated by the method of Bonsnes and Taussky (1945). Urines containing more than $3 \mathrm{mg}$./l. or less than $1 \mathrm{mg}$./l. of creatinine were discarded. This was rarely necessary.

\section{Results}

Normal Exposure Coefficients.-These were determined on morning urine specimens from 35 healthy persons who had not been exposed to carbon di- sulphide. People were included with various diets, including some rich in sulphur compounds. Values of $E$ (the exposure coefficient) were all within the range 10 to 6.5 . Persons exposed to 30 to $50 \mathrm{mg} . / \mathrm{m}^{3}$ of carbon disulphide and alcoholics treated with disulfiram also gave normal values. (Vašák in a personal communication stated that two to three hours after disulfiram treatment $E$ was decreased. We analysed morning specimens.)

Exposure Coefficient in Exposed Workers.-In various operations in a factory making viscose rayon, we made parallel determinations of carbon disulphide in the working atmosphere and the exposure coefficient, $E$, in the urine of exposed workers. The concentration of carbon disulphide in the working atmosphere varied according to the place and time of sampling. In spite of these variations, it was possible to get information on the level of exposure in various operations.

We analysed urine specimens taken three times during the day: just before the beginning of the work (6 a.m.), in the middle of the work (10 a.m.), and at the end of the work ( 2 p.m.).

In the Table the results are presented and operations are listed according to the level of exposure. The last column gives the average concentration in 8 which work was carried out as calculated from the exposure coefficients. The calculation is based on work by Vašák et al. (1963) on volunteers exposed to carbon disulphide in an exposure chamber. Values of $E$ were related graphically to the concentration of carbon disulphide in the atmosphere.

TABLE

VALUES OF EXPOSURE COEFFICIENT IN URINE OF WORKERS IN VARIOUS OPERATIONS IN A VISCOSE FACTORY

\begin{tabular}{|c|c|c|c|c|c|c|}
\hline \multirow{2}{*}{ Operation } & \multirow{2}{*}{$\begin{array}{l}\mathrm{CS}_{2} \text { in Air } \\
\text { (mg./m. }{ }^{3} \text {,') } \\
\text { min.-max.) }\end{array}$} & \multirow{2}{*}{$\begin{array}{l}\text { No. of } \\
\text { Observed } \\
\text { Workers }\end{array}$} & \multirow{2}{*}{ Time } & \multicolumn{2}{|c|}{ No. of Workers and Exposure Coefficient } & \multirow{2}{*}{$\begin{array}{c}\text { Evaluation of } \\
\text { Average Exposure } \\
\left(\mathrm{mg} . / \mathrm{m} .^{3}\right)\end{array}$} \\
\hline & & & & $\begin{array}{c}\text { Normal } \\
10-6.5\end{array}$ & $\begin{array}{c}\text { Decreased } \\
6 \cdot 5-0\end{array}$ & \\
\hline $\begin{array}{l}\text { Cell fibre production } \\
\text { Spinning }\end{array}$ & 23-808 & 21 & $\begin{array}{l}6 \text { a.m. } \\
10 \text { a.m. } \\
2 \text { p.m. }\end{array}$ & $\begin{array}{r}12 \\
5 \\
1\end{array}$ & $\begin{array}{c}9(6-4 \cdot 2) \\
16(5 \cdot 2-1 \cdot 3) \\
20(4 \cdot 1-1)\end{array}$ & Up to 250 \\
\hline Cutting and washing & $122-669$ & 8 & $\begin{array}{l}6 \text { a.m. } \\
10 \text { a.m. } \\
2 \text { p.m. }\end{array}$ & $\begin{array}{l}4 \\
0 \\
0\end{array}$ & $\begin{array}{l}4(6 \cdot 5-5 \cdot 4) \\
8(4 \cdot 7-1 \cdot 8) \\
8(4 \cdot 6-1 \cdot 6)\end{array}$ & Up to 230 \\
\hline Drying & $0-150$ & 4 & $\begin{aligned} 6 & \text { a.m. } \\
10 & \text { a.m. } \\
2 & \text { p.m. }\end{aligned}$ & $\begin{array}{l}4 \\
4 \\
4\end{array}$ & $\begin{array}{l}\mathbf{0} \\
\mathbf{0} \\
\mathbf{0}\end{array}$ & Below 50 \\
\hline Pressing of bales & $0-160$ & 4 & $\begin{array}{l}6 \text { a.m. } \\
10 \text { a.m. } \\
2 \text { p.m. }\end{array}$ & $\begin{array}{l}4 \\
4 \\
4\end{array}$ & $\begin{array}{l}0 \\
0 \\
0\end{array}$ & Below 50 \\
\hline Production of viscose rayon & $10-176$ & 10 & $\begin{array}{l}6 \text { a.m. } \\
10 \text { a.m. } \\
2 \text { p.m. }\end{array}$ & $\begin{array}{r}10 \\
10 \\
9\end{array}$ & $\begin{array}{l}0 \\
0 \\
1(4 \cdot 5)\end{array}$ & Up to 120 \\
\hline Production of sponges & $0 \cdot 8$ & 10 & $\begin{array}{l}6 \text { a.m. } \\
10 \text { a.m. } \\
2 \text { p.m. }\end{array}$ & $\begin{array}{l}5 \\
5 \\
5\end{array}$ & $\begin{array}{l}\mathbf{0} \\
\mathbf{0} \\
\mathbf{0}\end{array}$ & Below 50 \\
\hline
\end{tabular}




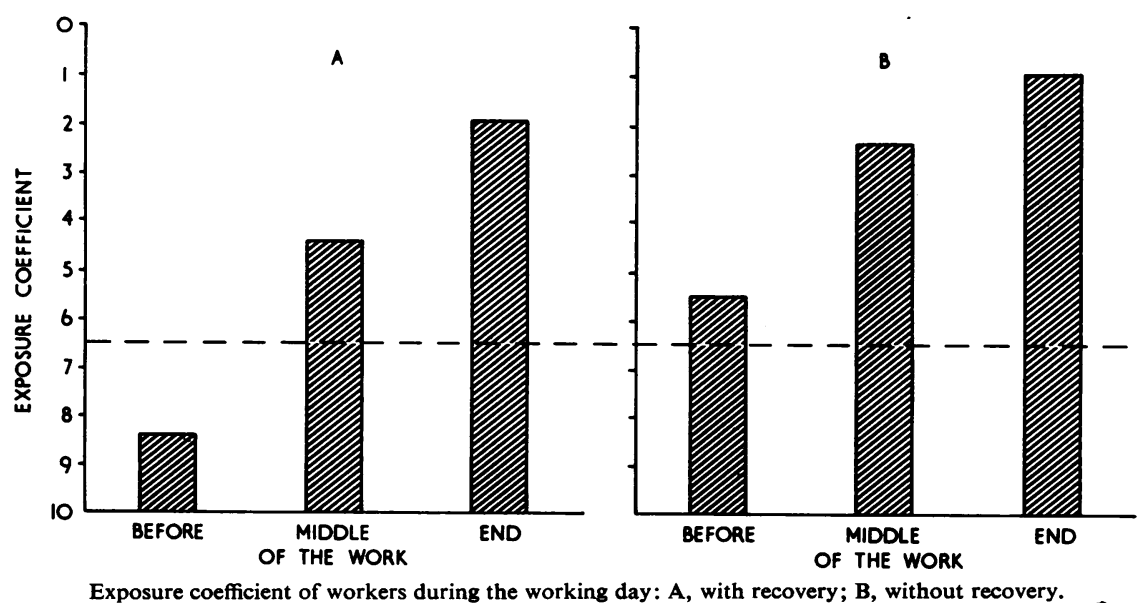

Urines from persons exposed to concentrations up to $50 \mathrm{mg} . / \mathrm{m}^{3}$ gave normal values of $E$.

There is a good correlation in our study between the average air concentrations calculated in this way and those obtained by direct determinations of atmospheric carbon disulphide. Thus the exposure coefficient determined on urines taken at the end of the working period gives a good estimate of total exposure during the day.

\section{Discussion}

From the results of the iodine-azide test three groups of workers can be distinguished. In what follows it must be remembered that a low exposure coefficient corresponds to a high exposure.

1. Those with normal values both before and after the working period. These are unlikely to have been exposed to more than $50 \mathrm{mg} . / \mathrm{m}^{3}$ during the working period. The maximum acceptable concentration in Yugoslavia is $33 \mathrm{mg} . / \mathrm{m}^{3}$, and probably most had not been exposed to average concentrations higher than this.

2. Those with normal values at the beginning of the period but lowered values at the end. These had been exposed but recovered overnight, at least in so far as excretion of metabolites was concerned. A typical case is shown in Figure A.

3. Those with decreased values at the beginning of the working period which decreased still further during it. These had been highly exposed and were still excreting metabolites the next morning. A typical case is shown in Figure B.

Why does this third group not recover completely? The study is being continued to find out whether the lack of recovery is due to especially high exposure or to factors such as constitution, onset of clinical poisoning, or a different way of life. It is necessary to determine whether recovery takes place over the week-end. Possibly lack of recovery is an early sign of poisoning. If so, the iodine-azide test could be useful clinically.

In conclusion, the iodine-azide test is a simple, rapid, and cheap test of exposure to carbon disulphide. The exposure coefficient at the end of the working period is a reliable index of the average exposure during it; and the exposure coefficient at the beginning of the working period can show whether workers have recovered from previous exposure.

We wish to thank Dr. H. Stokinger of the U.S. Public Health Service, Cincinnati for valuable suggestions.

\section{REFERENCES}

Bonsnes, R. W., and Taussky, H. H. (1945). J. biol. Chem., 158, 581. Brieger, H. (1961). J. occup. Med., 3, 302.

Djurić, D. (1963). Arh. Hig. Rada, 14, 23.

Roubal, I., Vasák, V., and Kimmelová, B. (1963). Cs. Hyg., 8, 265.

Vasák, V.'(1963). Pracov. Lék., 15, 143.

Y, Vanexek, M., and Kimmelová, B. (1963). Ibid., 15, 145. 